\title{
IDENTIFICATION OF RELEVANT STAKEHOLDERS WITHIN A RESILIENT CITY IN THE SLOVAK REPUBLIC
}

\author{
Ján Havko, ${ }^{1}$ Michal Titko, ${ }^{2}$ Jana Kováčová ${ }^{3}$
}

\begin{abstract}
Apparently, there is a significant increase in the occurrence of disasters and their negative consequences. It is believed that the main reason of this problem is related to climate change. In recent years, several approaches and efforts related to the topic of climate changes have been researched and in some cases also implemented. One of them is the resilient city concept as a tool dedicated for enhancing resilience and decreasing the vulnerability of a city and its citizens in case of a disaster. In this article, the concept of the resilient city is briefly described. The very important role within the resilient city represents the stakeholders. The understanding of the stakeholders' possible participation in city resilience building is important for city security. For that purpose, the relevant stakeholders' identification is necessary. Our research was conducted with regard to the data from the Step Up project and takes into consideration recommendations from the resilient city concept.
\end{abstract}

JEL Classification Numbers: H12, H70, Q54; DOI: http://dx.doi.org/10.12955/cbup.v5.917

UDC Classification: 303.35 .36

Keywords: disasters, resilient city, stakeholders

\section{Introduction}

In this article, we deal with the issue of resilience and the resilient city concept. Implementation of any project or concept requires cooperation between the wider community of actors who are more or less interested in the project objectives and also have different expectations of the project outcomes. Moreover, actors' engagement offers cities several benefits as a broader knowledge base for the decision making process, improvement of the quality and effectiveness of projects, further opportunities for joint projects, long-term support for strategies and actions in the city, and more robust and transparent decision making (Step Up Project, 2015). Therefore, the focus is placed mainly on the identification of interested parties (actors) - "stakeholders", who participate in building the resilient city. The term "stakeholder" refers to the person or group that has an interest in the success or performance of the system (subject, entity, project, concept, etc.), or can influence its success or performance (Grasseová, 2010). We can also identify stakeholders as interested groups. By consideration of the possible interest of actors in taking part in resilient city building it is possible to identify relevant stakeholders within the society and this is our intention to do so within this article.

\section{Literature review}

Based on the statistics and literature review (Groenemeijer et al., 2016; Bouwer, 2011; Guba-Sapir, Hargitt \& Hoyois, 2004; Luskova, Dvorak \& Leitner, 2015) it can be argued that there is an increasing trend of disasters occurrence. At the same time due to the higher intensity of disasters, more severe impacts can be observed. As a trigger of such events were identified mainly climate change aspects (Groenemeijer et al., 2016; Bouwer 2011; Guba-Sapir, Hargitt \& Hoyois, 2004). In order to address the development of current disasters, several guidelines (directives) and measures have been adopted by the organizations of international crisis management. The topic of climate change was addressed in the Paris climate Agreement (2016) and in frameworks Sendai (2015), Hyogo (2005) and Yokohama (1994). These documents are focused mainly on the issues of society's resilience as a concept of civil protection. Implementation of the resilient city concept also has specific areas which as well as having issues of risk management and crisis management, also do not provide direct and immediate outcomes for the actors in terms of profit (monetary or otherwise). Priorities and related outcomes within the resilient city concept are set as follows: (1) the understanding of disaster risks, (2) enhancing of risk governance in order to manage these risks, (3) investing in measures leading to disaster risk reduction in relation to resilience, (4) enhancing disaster preparedness and disaster response and recovery "Build Back Better" (UNISDR, 2015). Therefore, it is necessary to analyze the behavior (motivation, opportunities, interest, and responsibility) of stakeholders within society (system) in achieving these priorities and outcomes.

\footnotetext{
${ }^{1}$ Faculty of Security Engineering, University of Žilina, jan.havko@fbi.uniza.sk

${ }^{2}$ Faculty of Security Engineering, University of Žilina, michal.titko@fbi.uniza.sk

${ }^{3}$ Faculty of Security Engineering, University of Žilina, jana.kovacova@fbi.uniza.sk
} 


\section{Behaviour, Interests and Responsibility of the Subjects within the Society}

Every system's subject (actor) has an interest to satisfy their needs within that system. Such a satisfaction can be reach at the expense of other system's subjects. By decomposition of the system into components (interest areas) with several active subjects, there can be often recognized a contradiction between individual interests of every subject. As an example, a business environment can be assumed to be an inseparable part of each city, but our focus is a similar environment - the resilient city.

On the one hand, the primary interest of all business subjects is to maximize their profit. This effort is understandable and justified but makes us think about the way how that profit is achieved. On the other hand, the primary interest of the resilient city concept is not the economic profit of the subject (it can be seen as a secondary interest because prevention can save resources in the future), but it is a communitybased interest. As it was stated, the profit or any interest are mainly achieved at the expense of the other subject in the system. This is one of the main reasons why it is necessary to consider certain restrictions on the personal interests of a subject within a system. The possible restrictions can be provided and explain by two concepts: (1) the social contract and (2) ethics of responsibility.

Enlightenment thinkers (e.g., Thomas Hobbes, John Locke and Jean-Jacques Rousseau) have introduced the concept of the social contract. Acceptation of that concept would release individuals (and subjects) out of the constant whole-society fight for wealth, and they voluntarily gave up part of their rights, freedoms, and profits. They would achieve a legal state that would guarantee the same rights and duties of all members of a system (society). The concept of the social contract is present in today's society, and its justification is the basis of the current legal as well as social system.

Ethics of responsibility obliges the actors (subjects) to take a stand and be responsible for the (foreseeable) consequences of their actions (Machalová, 2008). Karl-Otto Apel (1922) as one of the founders of this approach to ethical issues, considered three levels within the responsibility structure. The first one is the subject of responsibility (the holder). It is the responsibility of a particular person (in our case it can be seen as representative of a social group or a stakeholder) who is able to correctly define his objectives given the current interests of the community to which it belongs and considering the direct and indirect consequences of their actions. The second level is formed by the object of an action - for what is the holder responsible. The last third level of responsibility creates the responsible action (behavior) itself, to whom we are actually responsible. Formulating of the responsible behavior and the definition of its scope is a collective issue because human responsible behavior is meaningful only in the context of collective choice (Machalová, 2008).

The idea of a subject's responsibility to a worldwide population is a theoretical possibility whose practical use is almost unfeasible. In contrary, a feasible project is the responsibility of the local community and its individual subjects - stakeholders. Just the ethics of responsibility gives the community stakeholders a tutorial on how to act and enhance the living standards and resilience of community. Obviously, each stakeholder can be interested in the community through various ways. Therefore, it is important to identify and treat the stakeholders individually.

\section{Resilient City's Stakeholders Identification}

There is no binding definition or strict interpretation of stakeholders within a city (neither in a resilient city). In order to identify relevant stakeholders within a resilient city we have conducted the basic literature study and we have also examined several reports mainly about implementation of the resilient city concept and about familiar concepts as well (e.g. the smart city concept). Within the mentioned sources, there have been identified mainly stakeholders as groups not stakeholders as individuals. These groups include academia, local and regional administrations, industry and commerce, finance, energy suppliers, ICT partners, communication companies, innovation bodies, international companies and citizens (Ielite, et al., 2015; Rotterdam Resilience Strategy, 2016; Resilient San Francisco, 2016). Identification of specific stakeholders within the resilient city is missing or is performed only partially.

For the purpose of the further resilient city research and in particular for its more stable implementation, we have conducted the identification of specific relevant stakeholders. The first step was a selection of the relevant stakeholders who (Step Up Project, 2015):

- have interests and activities relating to the issue in question (resilience),

- can provide information, expertise and resources required for effective policy making, 
- $\quad$ are key players in ensuring successful implementation of disaster resilient city

We have been also considering two main aspects:

- the city aspect (stakeholder groups within each city by which every city's resilience is built) we assume three stakeholders groups:

0 the application of the resilient concept and the solution to strategic tasks is the responsibility of the city (or municipality), the city government and public administration, will be the first and main stakeholder group,

0 the resilient city concept is citizen-oriented and therefore, the citizens and societies (communities in the cities) will definitely one of the main stakeholders in the city as well,

- a complementary position between communities and public administration (and government) is formed by the private sector (organizations, companies, institutions, agencies, etc.) which represent the third stakeholders group.

- the resilient city concept particularities aspect - the resilient city concept has defined seven basic components (UNISDR, 2012) of the city which should be addressed in order for successful implementation.

As an additional aspect for the identification of relevant stakeholders we used the Slovak Republic conditions where some stakeholders could differ due to specific differences in municipality and governance structure.

These aspects represent our starting point for stakeholders' identification and they are illustrated in Figure 1. This figure also illustrates a close relationship between the mentioned aspects. These aspects and related components can be found in every city (municipality). However, in some cases we may encounter some specifics which are not taken into consideration. Each city can vary based on their size, population number, social structure, spatial structure, level of development, governance, etc. From that reason they can also differ in the structure of city stakeholders - some of the stakeholders could be missing within the city (e.g. city does not have an university) or new ones could occur. Every particularities could be included in further identification and analysis if needed.

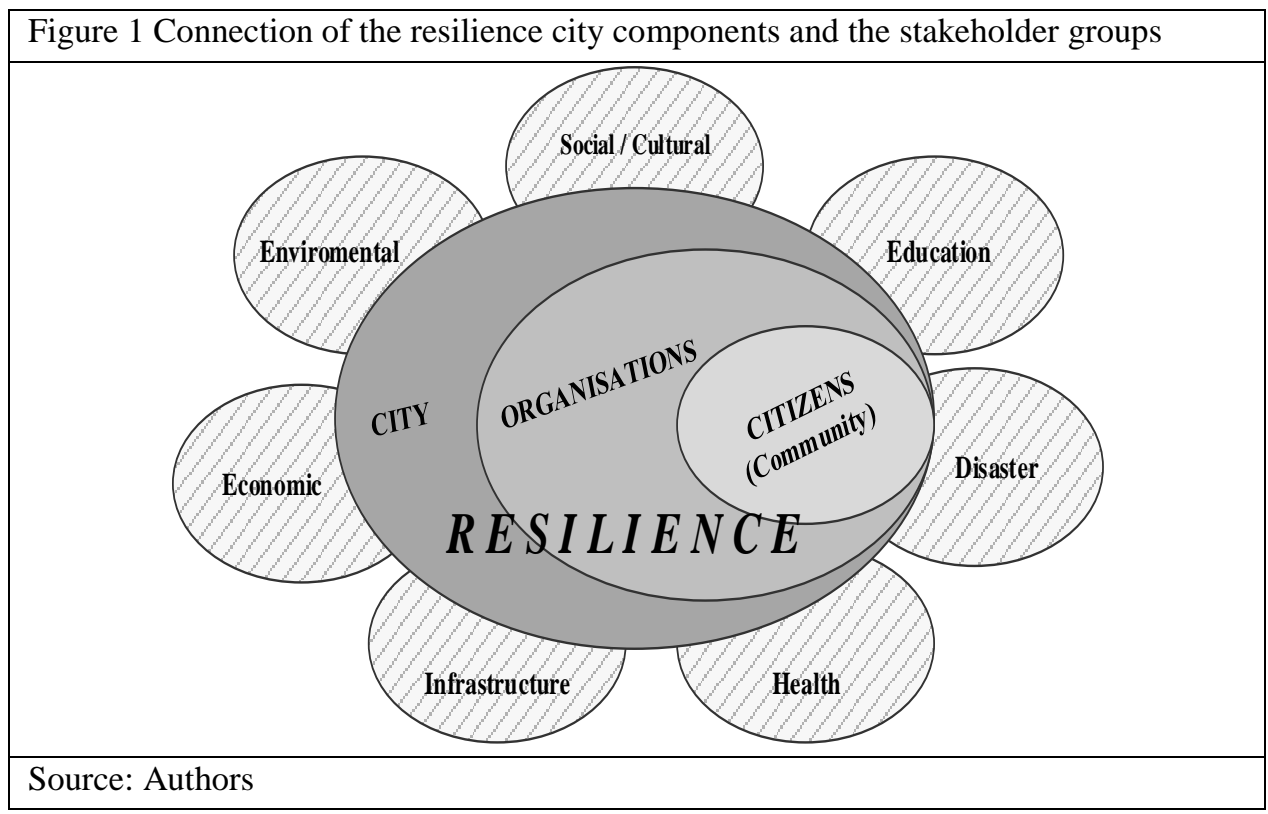

Based on the above mentioned aspects and components of the resilience city, the relevant stakeholders were identified as follows (Table 1). We assume that each of the stakeholder will be represented by a responsible representative (delegate) or by a group of representatives if needed. The leading position should be taken by representatives of city government and they should take part in all others interest areas as well. This is dictated by practical consideration because achieving a resilient city status is primarly the main task of the city leaders. City representatives, in some cases, may lack sufficient knowledge and experience in dealing with issues of crisis management, vulnerability reduction, disaster 
preparedness enhancing, or resilience enhancing, we assume a close cooperation with rescue services, risk managers as well as experienced subject-matter experts.

Table 1: Resilient city's stakeholders and interest areas

\begin{tabular}{|c|c|}
\hline Government & Education \\
\hline $\begin{array}{l}\text { Local government } \\
\text { Regional and local administration active in all } \\
\text { other interest areas } \\
\text { International agencies and institutions }\end{array}$ & $\begin{array}{l}\text { Education institutions (universities, etc.) } \\
\text { Research institutions } \\
\text { Other institutions which provide education } \\
\text { (professional courses and trainings) related to the } \\
\text { issue of civil preparedness }\end{array}$ \\
\hline Health & Infrastructure (transport) \\
\hline $\begin{array}{l}\text { Providers of healthcare (hospitals, clinics, health } \\
\text { centres, etc.) } \\
\text { Pharmaceutic companies }\end{array}$ & $\begin{array}{l}\text { Transport, mobility, logistic companies (private, } \\
\text { public) } \\
\text { Information and Communication services providers } \\
\text { Energy suppliers, agencies, utilities (electricity, gas, } \\
\text { oil, heat) } \\
\text { Water and waste management and agencies }\end{array}$ \\
\hline Society and Culture & Disasters \\
\hline $\begin{array}{l}\text { Citizens } \\
\text { Relevant social groups (representatives of } \\
\text { society - civic associations: workers, students, } \\
\text { ethnic group, religion representatives, etc.) } \\
\text { Political parties } \\
\text { Social services centres }\end{array}$ & $\begin{array}{l}\text { Integrated Rescue Services representatives } \\
\text { NGO's and other organised civil society } \\
\text { representatives (Red Cross, voluntary firefighters, } \\
\text { other organised voluntary groups, etc.) } \\
\text { Private companies which are active in disasters } \\
\text { solutions } \\
\text { Risk assessment companies (consultants, etc.) } \\
\text { Spatial planning subjects (building companies, } \\
\text { developers, chambers of architects and engineers) }\end{array}$ \\
\hline Environment & Economy \\
\hline $\begin{array}{l}\text { Companies with the potential of environmental } \\
\text { pollution }\end{array}$ & $\begin{array}{l}\text { Private sector (banks, business, industry, etc.) } \\
\text { Trade unions } \\
\text { Employment agencies }\end{array}$ \\
\hline
\end{tabular}

\section{Conclusion}

The resilient city is a concept by which a city adopts adequate measures to be able to minimize direct and indirect consequences of a disaster. It is also capable of a prompt and quick restoration of basic services, social, institutional and economic activities in the city after a disaster. We argue that the provided stakeholders' identification method can serve as a basis for further research and for the implementation of the resilient city concept. Identification of the relevant stakeholders should also serve for their further analysis and this is our intention to do so. By understanding the stakeholders' behaviour, interest, expectations, and responsibility within the process of building a resilient city it is possible to involve them and help them move towards a resilient city status. For explanation of these features the social contract concept and concept of ethics of responsibility can be used. On the one hand, we assume that there will be considerable similarities within the implementation of the resilient city concept and engagement of stakeholders into that process, but on the other hand, the particularities of each city (and stakeholders) should lead to an individual approach for each city and in particular to each stakeholder. Our intention is the analysis of relevant stakeholders of the practical example within the city Žilina in the Slovak Republic.

\section{Acknowledgements}

This work was supported by internal grant IGP201602 Application of resilient city concept in Žilina city. 


\section{References}

Bouwer, L.M. (2011). Have Disaster Losses Increased Due to Anthropogenic Climate Change? In: Bulletin of the American Meteorological Society. DOI: http://dx.doi.org/10.1175/2010BAMS3092.1

Grasseová, M., et al. (2010). 33 nejpouživanějšich metod strategického řizení. [33 Most Commonly Used Methods of Strategic Management] Brno: Computer Press, ISBN 978-80-251-2612-9, 325 pp.

Groenemeijer, P., et al. (2016). RAIN Project. D2.5 Present and Future Probability of Meteorological and Hydrological Hazards in Europe.

Guba-Sapir, D., Hargitt, D., Hoyois, P. (2004). Thirty years of natural disasters 1974 - 2003: The numbers. Brussel: Louvain-la-Neuve, 190 pp. ISBN 2-930344- 71-7.

Ielite, I., et al. (2015). Step Up Project. D2.1Stakeholder analysis and engagement plan.

Luskova, M., Dvorak, Z., Leitner, B. (2015). Impact of Extreme Weather Events on Land Transport Infrastructure. Transport Means 2015. Transport Means - Proceedings of the International Conference. pp. 306-309.

Machalová, T. (2008). Etika zodpovednosti. [Ethics of Responsibility]. Karl-Otto Apel. In Remišová, A. (ed.) Dejiny etického myslenia. [History of etich thinking]. Bratislava: KALLIGRAM, ISBN 978-80-8101-103-0, p. 691-701.

Resilient San Francisco. (2016). Stronger Today, Stronger Tomorrow. Strategy document. Part of 100 Resilient Cities. Rotterdam Resilience Strategy. (2016). Consultation Document. Part of 100 Resilient Cities.

Step Up Project (2015). Identifying and Engaging Stakeholders. Retrieved from: http://www.stepupsmartcities.eu/ToolsandInspiration/EnergyPlanning/Stakeholders/tabid/3264/Default.aspx

UNIDSR. (2012). How to make cities more resilient a handbook for local government leaders. Geneva: UN. Retrieved from: http://www.unisdr.org/files/26462_handbookfinalonlineversion.pdf

UNISDR, Sendai Framework. (2015). Geneva: United Nations. 